\title{
OCZEKIWANIA OSÓB PODRÓŻUJĄCYCH A INTEGRACJA PARKINGÓW Z MIEJSKIM SYSTEMEM TRANSPORTU ZBIOROWEGO
}

\begin{abstract}
Wzrost liczby pojazdów powoduje wiele skutków negatywnych. Oprócz tych powszechnie znanych, jak zanieczyszczenie, hałas, wypadki, pojawia się, zwłaszcza w centrach dużych miast kongestia ruchu, utrata terenów zielonych, nielegalne parkingi, zmiany w krajobrazie itd. Sytuacja może ulec częściowej poprawie dzięki zmianie zachowań kierowców oraz budowie parkingów Park and Ride, pozwalających na pozostawienie na obrzeżu miasta samochodu na parkingu i kontynuację podróży transportem zbiorowym. Aby zachęcić kierowców do wyboru takiego sposobu podróży, należy zintegrować budowę i działanie parkingów z miejskim systemem komunikacji zbiorowej. Identyfikacja potrzeb podróżnych, może pozwolić na lepsze dopasowanie infrastruktury i organizacji komunikacji zbiorowej do oczekiwań kierowców, a przez to do większej popularności systemu oraz usprawnienia jego funkcjonowania. Celem artykułu jest przedstawienie oczekiwań osób podróżujących komunikacją zbiorową, w kontekście integracji i dostosowania parkingów, w tym specjalizowanych parkingów Park and Ride, do systemu komunikacji publicznej i wymogów podróżnych. Wykorzystane metody badań to analiza porównawcza i badania ankietowe, realizowane wśród kierowców i mające na celu ocenę poszczególnych cech parkingów. W artykule przedstawiono preferencje w zakresie czynników komunikacji zbiorowej, których znajomość może być wykorzystana do efektywnej obsługi zintegrowanego systemu parkingów Park and Ride i komunikacji zbiorowej oraz ocenę czynników wpływających na jakość parkingów. Informacje te mogą być wykorzystane do likwidacji luki jakościowej między oczekiwaniami podróżnych, którzy korzystają z systemu, a jakością dostarczanych usług.
\end{abstract}

Słowa kluczowe: parking, Park and Ride, integracja w transporcie, zachowania kierowców, zachowania podróżnych, komunikacja zbiorowa

\section{Wprowadzenie}

Zasadniczym celem budowy i funkcjonowania parkingów typu Park and Ride (Parkuj i jedź) jest połączenie, czyli integracja korzyści wynikających z posiadania i posługiwania się samochodem osobowym, przez osoby dojeżdża-

\footnotetext{
${ }^{1}$ Waldemar Parkitny, Politechnika Krakowska, Wydział Inżynierii Lądowej, Instytut Zarządzania w Budownictwie i Transporcie, Zakład Transportu, ul. Warszawska 24, 31-155 Kraków, e-mail: wpark@usk.pk.edu.pl
} 
jące do dużych miast z miejscowości przyległych, z zaletami komunikacji zbiorowej, funkcjonującej w miastach.

Do najważniejszych zalet pojazdów osobowych, sprzyjających ich wykorzystaniu w dojazdach do miast, zaliczyć można m. in.:

- praktycznie nieograniczoną dostępność oraz elastyczność połączeń,

- bardzo duży komfort podróży,

- względnie niską cenę (często już przy 3 a nawet 2 osobach podróżujących porównywalną z ceną biletów komunikacji zbiorowej),

- możliwość wygodnego przewozu bagażu i zakupów.

Dla podróżnych zaletami przemieszczania się komunikacją zbiorową są:

- możliwość szybszej jazdy, w stosunku do podróży pojazdem osobowym, zwłaszcza w przypadku połączeń kolejowych, tramwajowych, metrem lub autobusami, które poruszają się po wydzielonych pasach ruchu,

- możliwość uniknięcia kongestii ruchu, szczególnie w godzinach szczytów,

- brak problemów z parkowaniem,

- brak opłat za parkowanie w centrach miast, często stosunkowo wysokich, zwłaszcza w przypadku konieczności codziennych dojazdów,

- możliwość wykorzystania czasu podróży na inne cele lub odpoczynek (w przypadku braku zatłoczenia w pojazdach komunikacji zbiorowej i dostępności miejsc siedzących).

$\mathrm{Z}$ tego punktu widzenia parkingi Parki and Ride są elementem infrastruktury, łączącym komunikację indywidualną z komunikacją zbiorową.

Analizy cech i funkcjonowania parkingów można dokonać z punktu widzenia dostosowania i integracji z systemami komunikacji zbiorowej, działającymi w miastach. Im projekt, lokalizacja, warunki korzystania, otoczenie i inne czynniki będą w większym stopniu dopasowane do oczekiwań kierowców, tym mniejsza będzie luka między jakością oczekiwaną a zaplanowaną i większa skłonność do korzystania z tego typu obiektów.

Celem artykułu jest przedstawienie oczekiwań osób podróżujących komunikacją zbiorową, w kontekście integracji i dostosowania parkingów, w tym specjalizowanych parkingów Park and Ride, do systemu komunikacji publicznej i wymogów podróżnych. Przyjęto przy tym założenie, że potrzeby osób podróżujących i korzystających ze zintegrowanego systemu Park and Ride z komunikacją zbiorową w miastach $\mathrm{w}$ zakresie realizacji podróży, można podzielić na trzy fazy:

- fazę związaną z podróżą od miejsca wyjazdu do parkingu przesiadkowego na realizację tych potrzeb wpływ będzie miał przede wszystkim stan techniczny dróg dojazdowych, sposób sterowania ruchem drogowym oraz jego natężenie,

- fazę związaną z parkowaniem pojazdu - wpływ na nią mają właściciele i zarządcy parkingów, 
- fazę związaną z podróżą od parkingu przesiadkowego do miejsca docelowego podróży środkami komunikacji zbiorowej - wpływ na nią ma zwłaszcza sprawnie działający system komunikacji zbiorowej.

Założono, że oczekiwania kierowców w zakresie standardu obsługi w ostatniej fazie, nie będą znacząco odbiegały od oczekiwań pozostałych podróżnych.

\section{Definicja integracji i jej obszary}

Integracja oznacza połączenie wielu elementów w całość. Dzięki niej możliwe jest osiągniecie dodatkowych korzyści, niemożliwych w przypadku atomizacji działań, oraz uzyskanie efektu synergii. W przypadku podmiotów uczestniczących w procesie integracji, jej efektem jest zmniejszenie ich niezależności, związane z koniecznością podporządkowania się regułom wynikającym z konieczności integracji, jak również z podjęciem dodatkowego wysiłku w celu sprostania jej wymogom.

Wśród celów integracji transportu pasażerskiego wymienia się:

- zorganizowanie ,atrakcyjnych warunków podróżowania transportem zbiorowym na cały, rozpatrywanym obszarze,

- wzmocnienie konkurencyjnej pozycji transportu zbiorowego w stosunku do transportu indywidualnego, realizowanego własnym samochodem osobowym,

- obniżenie kosztów przewozów przez szersze możliwości ograniczenia kosztownej bezpośredniości połączeń oraz likwidacji substytucyjności linii komunikacyjnych,

- optymalizację nakładów ponoszonych na transport pasażerski w skali obszaru integracji,

- uzyskanie możliwości prowadzenia polityki transportowej w efektywny sposób." ([18] na podstawie [4]).

Dydkowski G. [3] wyróżnia poniższe obszary integracji w transporcie zbiorowym:

- informacji komunikacyjnej,

- oferty przewozowej np. w odniesieniu do koordynacji rozkładów jazdy i proponowanych standardów,

- budowę punktów przesiadkowych,

- integrację biletowo - taryfową.

Z kolei Wild P. wymienia [23]:

- integrację taryfową, wykorzystującą jeden bilet sprzedawany z wykorzystaniem miejskiej sieci dystrybucyjnej,

- integrację i koordynację rozkładową na poziomie miejskim (15 min.), metropolitalnym (30 min.) i regionalnym (1 godz.),

- integrację przestrzenną, związaną z przebudową węzłów autostradowych w węzły P \& R oraz dworców w węzły przesiadkowe, 
- integrację i koordynację infrastrukturalną, związaną z przejmowaniem przez samorządy linii kolejowych oraz powołaniem wspólnego regionalnego zarządu infrastruktury kolejowej i drogowej.

Zając A. podaje następujące płaszczyzny integracji [25]:

- rozkład jazdy,

- taryfa,

- informacja i identyfikacja,

- centra przesiadkowe.

Nieco inny wybór został przedstawiony przez Rutę L. [19] Są to płaszczyzny integracji:

- organizacyjno - prawna,

- taryfowa,

- informacyjna,

- funkcjonalna (przewozowa),

- infrastrukturalna.

Sprawne działanie sytemu Park and Ride, jako całości, wymaga działań integracyjnych $\mathrm{w}$ wymienionych obszarach, nie tylko na etapie organizacji połączeń komunikacji zbiorową obsługującą parkingi „Parkuj i Jedź”, ale również $\mathrm{w}$ fazie projektowania niezbędnej infrastruktury $\mathrm{w}$ węzłach przesiadkowych.

\section{Czynniki mogące wpływać na zachowania podróżnych i wybór środka transportu}

Najważniejszym czynnikiem mającym wpływ na zachowania kierowców, związane z wyborem sposobu podróży opartym o system Park and Ride, jest dostępność fizyczna tego typu parkingów, oraz ich odpowiednie położenie i dopasowanie $[12,15]$. Niestety, jedynym miastem w Polsce, gdzie zbudowano kilkanaście takich parkingów jest na razie Warszawa. Pozostałe miasta, choć uwzględniają $\mathrm{w}$ swoich politykach transportowych takie parkingi, na razie są na etapie planowania lub skromnych realizacji, jak Kraków, gdzie jest ich zaledwie dwa. Uzupełnieniem parkingów $\mathrm{P} \& \mathrm{R}$ realizowanych przez miasta i opartych o miejskie przedsiębiorstwa komunikacji zbiorowej, jest dość duża już grupa parkingów Park and Ride, wybudowanych w pobliżu dworców kolejowych przez spółki z grupy PKP [10, 14]. W przypadku tego typu parkingów dojazd do centrum miasta wykonywany jest przeważnie przy wykorzystaniu istniejących połączeń kolejowych.

Zakładając, że sieć parkingów zlokalizowanych wokół miast jest jednak wystarczająco duża, następnym problemem może być zmiana nawyków i skłonienie części kierowców do korzystania z systemu, wyjaśnienie jego zasad oraz zwiększenie komfortu, związanego z przesiadką i dalszą podróżą. Identyfikując zachowania podróżnych wynikające $\mathrm{z}$ ich preferencji dotyczących sposobów podróżowania, wykorzystano wyniki badań z tego zakresu, wykonanych 
w kilku miastach. Przyjęto, że oprócz możliwości pozostawienia pojazdu na parkingu zlokalizowanym przy trasie przejazdu, na obrzeżu miasta, na decyzję o wyborze takiego sposobu podróżowania wpływ będą miały warunki związane z dalszą podróżą, wykonywaną pojazdami komunikacji zbiorowej, tzn. po zostawieniu pojazdu na parkingu Park and Ride. Założono, że oczekiwania kierowców co do funkcjonowania komunikacji miejskiej po pozostawieniu auta na parkingu, będą podobne jak osób, które nie posiadają samochodu.

Kompleksowe Badania Ruchu wykonane w 2013 roku w Krakowie wskazały na wzrost zainteresowania podróżami samochodami osobowymi w stosunku do poprzednich badań: 33,7\% w 2013 r., 25,9\% w 2003 r. i 19,2\% w 1995 r. Jednocześnie zauważono spadek przemieszczeń realizowanych komunikacja zbiorową - 36,3\% w 2013 r., 43,2\% w 2003 r. i 48,6\% w 1995 r. Taka sytuacja może wynikać $\mathrm{m}$. in. ze wzrostu liczby pojazdów, jaki nastąpił w przeciągu kilkunastu lat, choć warto zauważyć, że liczba podróży komunikacją zbiorową jest nieco większa od tych, realizowanych samochodem prywatnym.

Czynniki motywujące do pozostawienia auta w domu i dojazd do śródmieścia komunikacją zbiorową, to w przypadku mieszkańców gmin sąsiadujących z miastem, a więc potencjalnych użytkowników parkingów Park and Ride [20]:

- zwiększenie częstotliwości kursowania komunikacji miejskiej (43,6\%),

- możliwość szybkiego dojazdu komunikacją miejską (39,4\%),

- możliwość pozostawienia pojazdu na bezpłatnym parkingu w pobliżu śródmieścia $(29,8 \%)$,

- poprawa komfortu podróżowania (21\%),

- możliwość pozostawienia pojazdu na płatnym parkingu w pobliżu śródmieścia $(7,9 \%)$.

Kolejność postulatów przewozowych uzyskana w ramach badań preferencji transportowych mieszkańców Gdyni w 2013 r. przedstawia się następująco [5]:

- bezpośredniość $(27,65 \%)$,

- częstotliwość (16,7\%),

- punktualność (16,05\%),

- dostępność (bliskość przystanku) (12,25\%),

- niski koszt $(10,85 \%)$,

- niezawodność dojazdu (5,95\%),

- prędkość $(5,35 \%)$,

- wygoda $(2,4 \%)$,

- rytmiczność (2\%),

- wyczerpująca informacja $(0,4 \%)$.

Suma ważona punktów uzyskanych w badaniach zachowań komunikacyjnych mieszkańców Raciborza [2] wskazała na następującą hierarchizację cech komunikacji zbiorowej:

- punktualność kursowania (2911 przyznanych punktów),

- częstotliwość (2475 przyznanych punktów), 
- czas podróży (2199 przyznanych punktów),

- bezpośredniość połączenia (1893 przyznanych punktów),

- bliskość przystanku (1374 przyznanych punktów).

Badania zachowań komunikacyjnych wykonane na Śląsku, w przypadku przydzielania ocen w skali od 1 do 10, wskazują na poniższą kolejność czynników jakościowych według badanych [24]:

- całkowity czas podróży,

- koszty podróży,

- możliwość zdecydowania o trasie przejazdu,

- bezpieczeństwo w pojeździe,

- odległość źródło - cel,

- temperatura,

- miejsce siedzące,

- czas oczekiwania na środek transportu,

- opady deszczu,

- miejsca postojowe w pobliżu celu.

Warto zauważyć, że niektóre z powyższych czynników, pomimo, że były wymienione przez respondentów jako osobne pozycje, jak np.: całkowity czas podróży i czas oczekiwania na środek transportu, zależą od siebie.

$\mathrm{Z}$ powyższych zestawień wynika, ze najważniejszymi czynnikami związanymi z wyborem pojazdów komunikacji zbiorowej są:

- częstotliwość,

- czas podróży,

- punktualność,

- bezpośredniość połączenia,

- dostępność (bliskość przystanku).

Podróżni chcą więc szybkiego, pewnego i wygodnego środka podróży, który może być substytutem dla dojazdów własnym pojazdem. Te cechy powinny więc być dominujące dla usługi, jaką jest możliwość skorzystania ze zintegrowanego systemu parkingów i komunikacji zbiorowej.

Dokonując analizy innych czynników jakościowych, które mogą wpływać na wybór środka transportu (tab. 1), można wyróżnić te, w których:

- wpływ organizatora omawianego systemu zintegrowanego, poprzez odpowiednie przygotowanie usługi, jest bezpośredni, np. czas przejazdu komunikacją zbiorową, odległość dojścia z parkingu do środka transportu, liczba kursów w różnych porach dnia, organizacja połączeń na głównych ciągach komunikacyjnych ograniczająca liczbę przesiadek, zapewnienie odpowiedniej liczby miejsc siedzących itd.,

- wpływ organizatora jest ograniczony, np. czas dojścia z parkingu do środka transportu zależy zarówno od położenia parkingu, jak i indywidualnych predyspozycji kierowców, podobnie odległość dojścia ze środka transportu do celu zależy od odpowiedniego umiejscowienia przystanków w pobliżu 
głównych, zidentyfikowanych wcześniej celów podróży, jak: uczelnie, duże biura, zakłady pracy, ale również od potrzeb pasażerów związanych z daną podróżą i jej celem,

- wpływ organizatora nie istnieje lub jest znikomy, np. warunki atmosferyczne.

Ponadto można zauważyć, że w przypadku niektórych miast funkcje zarządzania infrastrukturą, w tym parkingową, rozdzielone są od funkcji, które związane są z funkcjonowaniem transportu miejskiego i realizowane przez różne instytucje. Utrudnia to przygotowanie spójnej i satysfakcjonującej dla użytkowników systemu zintegrowanej oferty komunikacji miejskiej i parkingów P \& R.

Wyjaśnienia mogą wymagać przedstawione w tab. 1 kryteria czasowe.

Tabela 1. Czynniki jakościowe wpływające na wybór środka transportu oraz możliwość wpływu na dany czynnik poprzez odpowiednią infrastrukturę i organizację zintegrowanego systemu parkingów i komunikacji zbiorowej

Table 1. Qualitative factors influencing on choice of mean of transport and possibility of influence on particular factor by suitable infrastructure and organization of the integrated system of car parks and collective communication

\begin{tabular}{|c|c|c|}
\hline Kategoria & Czynniki & $\begin{array}{c}\text { Możliwość } \\
\text { wpływu na dany } \\
\text { czynnik }\end{array}$ \\
\hline \multirow{4}{*}{ Czasowe } & czas przejazdu komunikacją zbiorową & + \\
\hline & czas dojścia do środka transportu & $+/-$ \\
\hline & czas oczekiwania na środek transportu & $+/-$ \\
\hline & czas dojścia ze środka transportu do celu & - \\
\hline \multirow{3}{*}{ Przestrzenne } & odległość źródło - cel & - \\
\hline & odległość dojścia do środka transportu & + \\
\hline & odległość dojścia ze środka transportu do celu & $+/-$ \\
\hline \multirow{3}{*}{ Dostępność } & liczba przesiadek & + \\
\hline & pora dnia & + \\
\hline & miejsca postojowe w pobliżu celu & $+/-$ \\
\hline \multirow{4}{*}{ Atmosferyczne } & temperatura & - \\
\hline & opady deszczu & - \\
\hline & opady śniegu & - \\
\hline & śliska nawierzchnia & $+/-$ \\
\hline \multirow{6}{*}{ Inne } & możliwość decydowania o trasie przejazdu & - \\
\hline & możliwość "bycia dowiezionym" na miejsce & $+/-$ \\
\hline & miejsca siedzące & + \\
\hline & koszty podróży & + \\
\hline & bezpieczeństwo w pojeździe & + \\
\hline & przyzwyczajenia (nawyk) & $+/-$ \\
\hline
\end{tabular}

Legenda: (+ tak, - nie, +/- częściowo)

Legend: (+ yes, - no, +/- to a certain degree)

Źródło: opracowanie własne przy wykorzystaniu klasyfikacji zawartej w [24] 
Na całkowity czas podróży składa się: czas przejazdu komunikacją zbiorową, na który można wpływać poprzez odpowiednią infrastrukturę i funkcjonowanie komunikacji zbiorowej (np. zorganizowanie wydzielonych pasów ruchu dla autobusów i tramwajów, metro), czas dojścia do środka transportu (wpływ częściowy poprzez odpowiednie umiejscowienie przystanków i parkingów), czas oczekiwania na środek transportu (wpływ częściowy, zależny od czasu przybycia kierowcy na przystanek i częstotliwości kursowania pojazdów komunikacji zbiorowej) i czas dojścia ze środka transportu do celu podróży. Ponadto należy zwrócić uwagę na to, że np. ze względu na ukształtowanie terenu, obecność skrzyżowań z sygnalizacją świetlną itd., czas dojścia nie jest tożsamy $\mathrm{z}$ odległością między wymienionymi w tabeli punktami.

Analiza możliwości wpływu na poszczególne czynniki pozwala stwierdzić zbliżony rozkład czynników, na które można wpływać, o ograniczonym wpływie i czynników poza wpływem (tab. 1). Wśród tych, na które istnieje wpływ, można i tu znaleźć te, które wystąpiły w wyżej cytowanych badaniach, a więc: czas związany z podróżą, odległość dojścia do środka transportu, czyli dostępność (bliskość przystanku), liczba przesiadek - bezpośredniość połączenia, jak również: miejsca siedzące, koszty podróży, bezpieczeństwo w pojeździe.

Do zagadnienia wyboru można również podejść w inny sposób, czyli od strony oceny jakości parkingów, z których korzystają podróżni. Wprawdzie większość realizowanych w ostatnim okresie parkingów Park and Ride jest zwykle dobrze utrzymana i wyposażona, to jednak przy dojazdach z wykorzystaniem komunikacji zbiorowej część z kierowców zmuszona jest skorzystać z parkingów ogólnodostępnych. Wskazówką dla zarządców oraz projektantów, $\mathrm{m}$. in. w zakresie architektury, mogą być wyniki badań ankietowych, wykonane przez autora wśród użytkowników takich parkingów. Wyniki przedstawiono w tabeli 2 [13, 2012 r.]. Badania wykonano na grupie użytkowników pojazdów samochodowych z różnych miejscowości w Polsce, liczącej, po odrzuceniu kwestionariuszy niekompletnych i błędnych, 300 osób. W tej liczbie 44,4\% stanowiły kobiety, a 55,6\% mężczyźni. Jako metodę badawczą przyjęto kwestionariusze ankietowe, które rozdano, z prośbą o ich wypełnienie, kierowcom. Oceny dokonano w skali od 1 do 5 , gdzie 1 to ocena zła, a 5 to ocena bardzo dobra. Badani oceniali jakość parkingów, przyznając poszczególnym parametrom swoje oceny. 
Tabela 2. Wyniki badań ankietowych dotyczących oceny jakości parkingów. W tabeli przedstawiono średnią $\mathrm{z}$ ocen przyznanych przez badanych wybranym czynnikom, które wpływają na jakość parkingów i udział procentowy w ocenie

Table 2. The results of questionnaire investigations relating to opinion of car parks' quality. The table presents the average of marks given by investigated to chosen factors influencing on car parks' quality, and proportional participation in the estimation

\begin{tabular}{|c|c|c|c|c|c|c|c|}
\hline \multirow[b]{2}{*}{ Miejsce } & \multirow[b]{2}{*}{ Oceniany parametr } & \multirow[b]{2}{*}{$\begin{array}{c}\text { Średnia } \\
\text { ocena }\end{array}$} & \multicolumn{5}{|c|}{\begin{tabular}{|l|} 
Udział w ocenie [\%] \\
\end{tabular}} \\
\hline & & & \begin{tabular}{|c|} 
Bar- \\
dzo \\
dobrze
\end{tabular} & $\begin{array}{l}\text { Do- } \\
\text { brze }\end{array}$ & $\begin{array}{c}\text { Śred- } \\
\text { nio } \\
\text { dobrze }\end{array}$ & \begin{tabular}{|c|} 
Dosta- \\
te- \\
cznie
\end{tabular} & Źle \\
\hline 1 & $\begin{array}{l}\text { Wydzielenie miejsc parkingowych } \\
\text { dla niepełnosprawnych }\end{array}$ & 3,46 & 25,85 & 28,57 & 20,41 & 16,33 & 8,84 \\
\hline 2 & Rodzaj nawierzchni parkingu & 3,40 & 10,51 & 43,39 & 28,47 & 11,19 & 6,44 \\
\hline 3 & $\begin{array}{l}\text { Warunki dojścia z parkingu do celu } \\
\text { podróży }\end{array}$ & 3,36 & 8,93 & 37,46 & 37,46 & 13,06 & 3,09 \\
\hline 4 & $\begin{array}{l}\text { Ograniczenia w prędkości poru- } \\
\text { szania się wewnątrz parkingu }\end{array}$ & 3,33 & 8,50 & 36,39 & 37,76 & 14,29 & 3,06 \\
\hline 5 & $\begin{array}{l}\text { Oznakowanie parkingu na drogach } \\
\text { dojazdowych }\end{array}$ & 3,32 & 8,16 & 35,03 & 43,20 & 7,48 & 6,12 \\
\hline 6 & Oświetlenie & 3,28 & 8,78 & 39,53 & 29,05 & 16,55 & 6,08 \\
\hline 7 & $\begin{array}{l}\text { Oznakowanie bram wyjazdowych i } \\
\text { dróg ewakuacyjnych }\end{array}$ & 3,26 & 9,83 & 37,63 & 29,15 & 15,93 & 7,46 \\
\hline 8 & $\begin{array}{l}\text { Całodobowość funkcjonowania } \\
\text { parkingu }\end{array}$ & 3,24 & 15,81 & 27,49 & 29,55 & 18,90 & 8,25 \\
\hline 9 & Czystość parkingu & 3,23 & 7,12 & 40,34 & 29,83 & 14,24 & 8,47 \\
\hline 10 & Reputacja parkingu & 3,22 & 2,75 & 35,74 & 46,39 & 11,34 & 3,78 \\
\hline 11 & $\begin{array}{l}\text { Wielkość wyznaczonego pojedyn- } \\
\text { czego miejsca parkingowego }\end{array}$ & 3,17 & 5,78 & 38,10 & 31,29 & 17,01 & 7,82 \\
\hline 12 & $\begin{array}{l}\text { Wielkość dróg dojazdowych i ma- } \\
\text { newrowych na parkingu }\end{array}$ & 3,09 & 5,14 & 30,14 & 38,70 & 20,21 & 5,82 \\
\hline 13 & $\begin{array}{l}\text { Łatwość orientacji w układzie par- } \\
\text { kingu }\end{array}$ & 3,01 & 5,52 & 28,62 & 36,55 & 19,66 & 9,66 \\
\hline 14 & Wielkość parkingu & 3,00 & 4,76 & 31,29 & 35,03 & 17,01 & 11,90 \\
\hline 15 & Ogrodzenie & 2,94 & 6,78 & 28,47 & 29,49 & 22,03 & 13,22 \\
\hline 16 & Estetyka parkingu & 2,92 & 5,46 & 24,91 & 36,52 & 22,87 & 10,24 \\
\hline 17 & Brak ograniczeń czasu parkowania & 2,90 & 17,36 & 15,63 & 26,39 & 20,49 & 20,14 \\
\hline 18 & $\begin{array}{l}\text { Kompetencja i kultura obsługi par- } \\
\text { kingu }\end{array}$ & 2,87 & 5,12 & 22,18 & 39,25 & 21,84 & 11,60 \\
\hline 19 & Automaty biletowe & 2,80 & 5,54 & 25,26 & 29,76 & 22,15 & 17,30 \\
\hline 20 & $\begin{array}{l}\text { Identyfikacja literowo-numeryczna } \\
\text { pojedynczego } \\
\text { miejsca postojowego }\end{array}$ & 2,69 & 7,22 & 21,65 & 25,43 & 24,05 & 21,65 \\
\hline 21 & Zadaszenie & 2,56 & 6,85 & 18,84 & 26,03 & 19,86 & 28,42 \\
\hline 22 & $\begin{array}{l}\text { Wydzielenie chodników dla pie- } \\
\text { szych }\end{array}$ & 2,53 & 4,51 & 16,32 & 30,56 & 25,35 & 23,26 \\
\hline 23 & Cena za parkowanie & 2,52 & 7,56 & 12,71 & 27,84 & 27,49 & 24,40 \\
\hline
\end{tabular}


Tabela 2 (cd.). Wyniki badań ankietowych dotyczących oceny jakości parkingów. W tabeli przedstawiono średnią z ocen przyznanych przez badanych wybranym czynnikom, które wpływają na jakość parkingów i udział procentowy w ocenie

Table 2 (cont.). The results of questionnaire investigations relating to opinion of car parks' quality. The table presents the average of marks given by investigated to chosen factors influencing on car parks' quality, and proportional participation in the estimation

\begin{tabular}{|c|l|c|c|c|c|c|c|}
\hline \multirow{2}{*}{ Miejsce } & \multicolumn{1}{|c|}{ Oceniany parametr } & \multirow{2}{*}{$\begin{array}{c}\text { Średnia } \\
\text { ocena }\end{array}$} & $\begin{array}{c}\text { Bar- } \\
\text { dzo } \\
\text { dobrze }\end{array}$ & $\begin{array}{c}\text { Do- } \\
\text { brze }\end{array}$ & $\begin{array}{c}\text { Śred- } \\
\text { nio } \\
\text { dobrze }\end{array}$ & $\begin{array}{c}\text { Dosta- } \\
\text { te- } \\
\text { cznie }\end{array}$ & Źle \\
\hline 24 & System monitorowania & 2,49 & 2,36 & 16,16 & 30,98 & 28,96 & 21,55 \\
\hline 25 & Plan parkingu & 2,36 & 1,69 & 16,27 & 26,78 & 26,78 & 28,47 \\
\hline 26 & $\begin{array}{l}\text { Obecnośćn pracowników obsługi } \\
\text { parkingu }\end{array}$ & 2,34 & 2,03 & 14,58 & 26,44 & 29,15 & 27,80 \\
\hline 27 & $\begin{array}{l}\text { Odpowiedzialność właściciela par- } \\
\text { kingu na wyrządzone szkody }\end{array}$ & 2,28 & 3,61 & 9,03 & 29,60 & 27,44 & 30,32 \\
\hline 28 & $\begin{array}{l}\text { Obecność pracowników ochrony } \\
\text { parkingu }\end{array}$ & 2,27 & 3,44 & 11,68 & 24,05 & 30,58 & 30,24 \\
\hline 29 & $\begin{array}{l}\text { Sygnalizacja elektroniczna wol- } \\
\text { nych miejsc postojowych podawa- } \\
\text { na na parkingu }\end{array}$ & 2,15 & 4,51 & 13,54 & 18,40 & 19,10 & 44,44 \\
\hline 30 & $\begin{array}{l}\text { Zniżki za parkowanie dla stałych } \\
\text { klientów }\end{array}$ & 2,11 & 3,86 & 10,53 & 18,25 & 27,02 & 40,35 \\
\hline 31 & $\begin{array}{l}\text { Informacja o dostępności wolnych } \\
\text { miejsc parkingowych podawana na } \\
\text { drogach dojazdowych do parkingu }\end{array}$ & 2,00 & 3,74 & 9,86 & 20,75 & 14,29 & 51,36 \\
\hline 32 & $\begin{array}{l}\text { System naprowadzania na wolne } \\
\text { miejsca parkingowe }\end{array}$ & 1,67 & 2,06 & 5,84 & 11,68 & 18,21 & 62,20 \\
\hline 33 & Informacja głosowa & 1,59 & 0,35 & 4,93 & 13,03 & 16,90 & 64,79 \\
\hline
\end{tabular}

Źródło: opracowanie autora na podstawie [13]

Ankietowani przyznali oceny poniżej średniej, czyli 2,50, takim czynnikom, jak: system monitorowania, plan parkingu, obecność pracowników obsługi parkingu, odpowiedzialność właściciela parkingu na wyrządzone szkody, obecność pracowników ochrony parkingu, sygnalizacja elektroniczna wolnych miejsc postojowych podawana na parkingu, zniżki za parkowanie dla stałych klientów, informacja o dostępności wolnych miejsc parkingowych podawana na drogach dojazdowych do parkingu, system naprowadzania na wolne miejsca parkingowe i informacja głosowa. Czynniki te można podzielić na trzy grupy związane z:

- informacją - plan parkingu, sygnalizacja elektroniczna wolnych miejsc postojowych podawana na parkingu, informacja o dostępności wolnych miejsc parkingowych podawana na drogach dojazdowych do parkingu, system naprowadzania na wolne miejsca parkingowe i informacja głosowa, 
- bezpieczeństwem - system monitorowania, obecność pracowników obsługi parkingu, odpowiedzialność właściciela parkingu na wyrządzone szkody, obecność pracowników ochrony parkingu,

- kosztami parkowania - zniżki za parkowanie dla stałych klientów.

Grupy powyższych czynników mogą, więc stanowić obszar do działań, które zmierzają do poprawy istniejącej sytuacji. Warto zauważyć, ze dwa z trzech wymienionych czynników, które uzyskały słabą ocenę, a więc bezpieczeństwo i koszty, tym razem zostały odniesione do parkingów, a nie do środków komunikacji zbiorowej.

\section{Uwagi końcowe i wnioski}

System Park and Ride zapewnia połączenie zalet wynikających z możliwości dojazdu indywidualnego $\mathrm{w}$ terenach słabo zaludnionych, szczególnie gdy brak jest regularnych i częstych połączeń komunikacją zbiorową, oraz dojazdu transportem publicznym $\mathrm{w}$ miastach, który niejednokrotnie oferuje większą prędkość przejazdu oraz zredukowanie związanych z tym kosztów, w tym kosztów zewnętrznych.

Podstawowym problemem, który daje się obecnie zauważyć, jest duży deficyt miejsc parkingowych, występujący nie tylko w ścisłych centrach miast [16, 17], ale również w odniesieniu do ich przedmieść oraz miejscowości podmiejskich, w których można byłoby zorganizować parkingi typu „Parkuj i Jedź”. O ile konieczność budowy parkingów i węzłów przesiadkowych przy wjazdach do miast jest rozumiana i umieszczana we wszystkich politykach transportowych dużych ośrodków miejskich i miast wojewódzkich, o tyle takie czynniki jak np.:

- wysokie koszty pozyskania gruntu,

- nakłady na budowę parkingów,

- konieczność ponoszenia kosztów na bieżące utrzymanie zrealizowanych parkingów przesiadkowych,

- brak zrozumienia problemu,

mogą powodować u władz miejscowości przyległych do dużych miast niechęć do realizacji parkingów Park and Ride obsługujących te miasta. Działania integracyjne w sferze rozwoju sieci parkingów i zwiększania liczby miejsc na parkingach, należy więc prowadzić w sferze informacyjnej oraz współpracy na szczeblu miast i gmin przyległych do nich, niejednokrotnie będących miejscem zamieszkania sporej liczby użytkowników samochodów osobowych, codziennie przemieszczających się do miast w celach: zawodowych, edukacyjnych, zdrowotnych, kulturalnych i handlowych. Warto też zwrócić uwagę na fakt, iż pomimo znajomości zalet systemu w kraju oraz powszechności jego stosowania zagranicą, $w$ dalszym ciągu nie jest on w sposób spójny i zintegrowany z komunikacją miejską realizowany w miastach (z wyjątkiem Warszawy).

Aby system mógł należycie spełniać swoje funkcje, konieczne jest również spojrzenie na jego funkcjonowanie $\mathrm{z}$ punktu widzenia użytkownika. Zadanie 
to jest utrudnione, gdy poszczególne elementy systemu są rozproszone. Do elementów tych zaliczyć można:

- istniejącą infrastrukturę drogową (stan nawierzchni, drogi dojścia, odpowiednie oznakowanie),

- istniejącą infrastrukturę punktową (parkingi, ich wyposażenie, węzły przesiadkowe),

- sterowanie ruchem,

- przepisy prawne,

- procedury korzystania,

- opłaty za parkowanie,

- taryfikatory biletów komunikacji zbiorowej,

- organizację obsługi komunikacyjnej parkingów (częstotliwość i czas jazdy pojazdów komunikacji publicznej, godziny funkcjonowania, trasy przejazdu itd.),

- komfort i wyposażenie pojazdów,

- jakość informacji,

- bezpieczeństwo pojazdów pozostawionych na parkingu,

- obsługę parkingów i komunikacji zbiorowej.

Mnogość czynników, które należy zsynchronizować i zintegrować może powodować problemy. Jest to tym trudniejsze, im występuje większa liczba instytucji publicznych i podmiotów gospodarczych, odpowiedzialnych za funkcjonowania poszczególnych elementów systemu. Źródłem trudności mogą być odmienne interesy poszczególnych instytucji i przedsiębiorstw, nierzadko konkurujących ze sobą np. przy obsłudze określonych fragmentów miasta, jak również wpływ czynników zewnętrznych, koniecznych do uwzględnienia przez firmy uczestniczące w systemie, ale nie zawsze brane pod uwagę przez jego użytkowników.

Pomimo podobnych potrzeb przewozowych, posiadacze samochodów osobowych mając możliwość wyboru środka transportu, tzn. jazdy własnym pojazdem albo pojazdem komunikacji zbiorowej, mogą być mniej tolerancyjni w odniesieniu do czynników jakościowych środków komunikacji zbiorowej od osób, które własnego pojazdu nie mają. Mniejsza elastyczność kierujących pojazdami osobowymi na ofertę przewozową organizatorów transportu zbiorowego może skutkować rezygnacją z korzystania ze zintegrowanego systemu: P \& R i komunikacja zbiorowa. Spadające systematycznie od wielu miesięcy ceny ropy naftowej, przy jednoczesnym utrzymywaniu się stałych cen za bilety w komunikacji publicznej, dodatkowo wpływają na zwiększenie atrakcyjności komunikacji indywidualnej. Poznanie rzeczywistych oczekiwań kierowców, przekładające się na zwiększenie korzyści z korzystania z systemu Park and Ride, może przyczynić się do zmiany ich nawyków. Przytoczone wyniki badań wskazują, że ważne okazują się konkretne czynniki dotyczące przejazdu, takie jak np.: częstotliwość jazdy, punktualność, czas dojazdu, w odróżnieniu od spektakularnych, ale nie wymienionych przez podróżnych gadżetów umieszczanych w pojazdach, jak: elektroniczne plany miast, duże, kolorowe wyświe- 
tlacze w kasownikach, ekrany i reklamy telewizyjne czy Wi Fi. Czynniki te nie zastąpią pewnego i szybkiego środka komunikacji zbiorowej, jakiego oczekują kierowcy pojazdów osobowych, korzystający z komunikacji zbiorowej. Wpływają one jednak na uatrakcyjnienie i estetykę pojazdów, zachęcając do podróży zwłaszcza młode osoby, dla których często środek komunikacji zbiorowej jest jedynym, z którego mogą korzystać przy dojazdach do szkół i uczelni.

Przykłady decyzji podejmowanych w innych krajach, wskazują na jeszcze jeden aspekt związany z zachowaniami komunikacyjnymi kierowców, jakim jest czynnik finansowy. Choć działania takie są kosztowne, to tam, gdzie podjęto próbę wpływania na kierowców w celu rezygnacji z dojazdów samochodami osobowymi do centrów miast, poprzez opłaty za wjazd lub udzielane im różnego rodzaju gratyfikacji finansowych, osiągnięto rezultaty w postaci częściowej rezygnacji z używania własnych pojazdów, na rzecz komunikacji zbiorowej. Przykładem może być: Sztokholm - zarządzenie zmian, polegających na pobieraniu opłat za używanie samochodów w godzinach szczytu, dało efekt redukcji: 14\% dwutlenku węgla i tlenku azotu, od 30\% do 50\% strat czasu stania w korkach, od 20 do $25 \%$ liczby pojazdów w centrum miasta; Rotterdam - działanie odwrotne, nagradzanie zamiast karania (46\% osób uczestniczących w programie, polegającym na wypłatach $5 €$ przy rezygnacji z każdego dojazdu samochodem w pierwszym roku oraz $3 €$ po tym czasie przez dwa lata, zaprzestało wykorzystywać auto osobowe w godzinach szczytu, w celu dojazdu do pracy, co więcej: u ponad połowy zaobserwowano utrwalenie tego nawyku po zaprzestaniu programu); Drezno - dopłaty dla kierowców do biletów komunikacji zbiorowej w zamian za rezygnację z wykorzystywania samochodów osobowych oraz poprawa infrastruktury rowerowej (efekt to m. in.: redukcja liczby osób dojeżdżających własnym samochodem o 19\%, 650\% wzrost podróży pieszych, $49 \%$ wzrost dojazdów komunikacją zbiorową) [8].

Zagadnienie integracji parkingów z systemami komunikacji zbiorowej w miastach jest również poruszane w literaturze zagranicznej. Tematem badań są m. in.: wpływ parkingów, w tym Park and Ride, na kongestię ruchu, funkcjonowanie parkingów przykrawężnikowych, budowa modeli matematycznych, zagadnienia wprowadzania opłat za wjazd do centrów miast.

Jako przykład można podać pracę Jose Holguin-Veras, Wilfredo F. Yushimito, Felipe Aros-Vera, John (Jack) Reilly pt. „User rationality and optimal park-and-ride location under potential demand maximization" [7], w której przedstawiono oszacowanie miejsca oraz potencjalnego rejonu ciążenia parkingów P \& R.

Model programowania liniowego użyty do określenia miejsca położenia parkingów typu Park \& Ride został przedstawiony w artykule Felipe Aros-Vera, Vladimira Marianov, Johna E. Mitchella [1].

Model charakteryzujący wybór sposobu podróży z wykorzystaniem parkingów Park and Ride oraz zachowania osób podróżujących zaprezentowano w artykule Tian-Liang Liu, Hai-Jun Huang, Hai Yang, Xiaoning Zhang, pt. 
„Continuum modeling of park-and-ride services in a linear monocentric city with deterministic mode choice" [22].

W pracy pt. „Class of Comprenesive Optimization of Congested Road-Use Pricing and Parking Pricing" [6] autorzy rozważają wprowadzenie opłat za korzystanie z zatłoczonych odcinków dróg oraz opłat za korzystanie z parkingu. Ich celem może być zmniejszenie kongestii ruchu drogowego. Założono wprowadzenie poboru opłat za wjazd do zatłoczonych stref lub wprowadzenie systemu Park \& Ride, umożliwiającego parkowanie na granicy strefy i kontynuowanie podróży transportem publicznym.

Zagadnienie $\mathrm{m}$. in. wpływu parkingów na zatłoczenie ulic jest również rozważane przez Mei Zhenyu, Xiang Yiqiang, Chen Jun, Wang Wei [9]. Zwrócono w nim uwagę na parkowanie przykrawężnikowe, które jest częścią systemu parkowania w miastach, oraz na wpływ cen za parkowanie tego typu na stopień wykorzystania wolnych miejsc i redukcję zatłoczenia drogowego. Przeanalizowano również zachowania kierowców oraz wykonano probitowy model zachowań, który związany jest z wyborem miejsca parkowania samochodu.

Modele logitowe, wykonane na podstawie badań kierowców, dotyczących parkowania w warunkach polskich, przedstawiono w pracy W. Parkitnego [11].

Podawane są też przykłady inteligentnych systemów parkowania, w takich miastach jak np.: Kolonia, Helsinki, Stuttgart, Wiesebaden, Haga, przekazujących informacje o wolnych miejscach [21].

\section{Literatura}

[1] Aros-Vera Felipe, Marianov Vladimir, Mitchell John E.: p-Hub approach for the optimal park-and-ride facility location problem, European Journal of Operational Research 226 (2013) 277-285.

[2] Badania zachowań komunikacyjnych mieszkańców Raciborza 2005, http://debicaarchiwum.pl/images/file/Badania\%20zachowan\% 20komunikac_zawrtosc. pdf, \{dostęp: 24.09.2015 r.\}.

[3] Dydkowski G.: Warunki i bariery integracji miejskiego transportu zbiorowego na przykładzie miast Aglomeracji Górnośląskiej, Konferencja nt. polityki miejskiej w kontekście spójności polityki UE z latach 2007 - 2013, Katowice 2007. http://konferencja2007.silesia.org.pl/materialy/034_Gdydkowski.pdf $\quad\{$ dostęp: 27.10.2015 r.\}.

[4] Grzelec K.: Integracja komunikacji miejskiej w aglomeracjach miejskich, Transport Miejski, nr 5/2003.

[5] Hebel K: Postulaty przewozowe mieszkańców Gdyni w badaniach marketingowych na przykładzie badań bezpośrednich, Transport Miejski i Regionalny, nr 5/2015, Kraków 2015.

[6] Hi Feng, Chen Yan, Li Hengxin, Deng Lianbo: Class of Comprenesive Optimization of Congested Road-Use Pricing and Parking Pricing, Journal of Transportation Systems Engineering and Information Technology Volume 9, Issue 1, February 2009. 
[7] Holguin-Veras Jose, Yushimito Wilfredo F., Aros-Vera Felipe, Reilly John (Jack): User rationality and optimal park-and-ride location under potential demand maximization, Transportation Research Part B 46 (2012) 949-970.

[8] Kornalewski L., Malasek J.: Analiza skuteczności metod poprawy miejskich zachowań komunikacyjnych, Transport Miejski i Regionalny, nr 6/2015.

[9] Mei Zhenyu, Xiang Yiqiang, Chen Jun, Wang Wei: Optimizing Model of Curb Parking Pricing Based on Parking Choice Behavior, Journal of Transportation Systems Engineering and Information Technology, Vol. 10, Issue 1, February 2010, 99-104.

[10] Parkitny W.: Analiza parametrów parkingów realizowanych przez kolej w południowo - wschodniej Polsce, Transport Miejski i Regionalny, nr 3, marzec 2013.

[11] Parkitny W.: Analysis of chosen logit models to predict the behaviour of personal vehicles' drivers with reference to car parks choice, Logistyka, nr 6/2014, CD: część Logistyka - nauka, pp. 8383-8391.

[12] Parkitny W.: Model matematyczny wyboru lokalizacji miejsc przesiadkowych i parkingów dla systemu P \& R, Polityka parkingowa w miastach, Zeszyty Naukowo - Techniczne Stowarzyszenia Inżynierów i Techników Komunikacji Rzeczpospolitej Polskiej Oddział w Krakowie, seria: Materiały konferencyjne, nr 80, zeszyt 134, Kraków 2007.

[13] Parkitny W.: Ocena jakości parkingów na podstawie wyników badań ankietowych, Transport Miejski i Regionalny, nr 1, styczeń 2012.

[14] Parkitny W.: Park \& Ride and railway station's car parks in Małopolska and Podkarpacie provinces in Poland, $5^{\text {th }}$ International Conference Road and Urban Transport and Sustainable Development CMDTUR 2009, Slovak Republic, Žilina 2009.

[15] Parkitny W.: Wskaźniki oceny dopasowania parkingów, Logistyka, nr 4/2008.

[16] Parkitny W.: Analiza wykorzystania stref płatnego parkowania we Wrocławiu przez uprzywilejowane grupy kierowców, Magazyn Autostrady Budownictwo Drogowo Mostowe, nr 8-9/2016, str. 59-63.

[17] Parkitny W.: Zasady funkcjonowania i analiza wydawanych abonamentów do stref płatnego parkowania w Krakowie, Magazyn Autostrady Budownictwo Drogowo Mostowe, nr 7/2016, str. 42-46.

[18] Praca zbiorowa pod red. A. Rudnickego: Innowacje na rzecz zrównoważonego transportu miejskiego. Doświadczenia z realizacji projektu Unii Europejskiej CIVITAS - CARAVEL, Politechnika Krakowska, Wydział Inżynierii Drogowej i Kolejowej, Katedra Systemów Komunikacyjnych, Kraków 2010.

[19] Ruta L.: Transport publiczny w aglomeracji warszawskiej. Wybrane aspekty integracji - perspektywa organizatora, Konferencja „Region - Miasto - Kolej”, 30.03.2011, Warszawa 2011.

[20] Szarata A.: Wyniki badań podróży w Krakowie KBR 2013, Transport Miejski i Regionalny, nr 5/2015.

[21] Teodorović Dušan, Lučić Panta: Intelligent parking systems, European Journal of Operational Research 175 (206) 1666-1681. 
[22] Tian-Liang Liu, Hai-Jun Huang, Hai Yang, Xiaoning Zhang: Continuum modeling of park-and-ride services in a linear monocentric city with deterministic mode choice, Transportation Research Part B 43 (2009) 692-707.

[23] Wild P.: Transport szynowy w Aglomeracji Wrocławskiej, Konferencja „Region Miasto - Kolej”, 30.03.2011, Warszawa 2011.

[24] Sierpiński G.: Zachowania komunikacyjne osób podróżujących a wybór środka transportu w mieście, Prace Naukowe Politechniki Warszawskiej, Transport, Z. 84, Warszawa 2012.

[25] Zając A.: Zasady tworzenia zintegrowanej oferty w systemie transportu publicznego. rola, struktura, funkcje i odpowiedzialność integratora sytemu transportowego, Konferencja „Region - Miasto - Kolej”, 30.03.2011, Warszawa 2011.

\section{EXPECTATIONS OF TRAVELLERS AND INTEGRATION OF CAR PARKS WITH MUNICIPAL SYSTEM OF COLLECTIVE TRANSPORT}

\section{S u m m a r y}

The growth of number of vehicles causes many negative results. Except those widely known like pollution, noise, accidents, there appears, especially in centers of large cities, congestion of movement, loss of green terrains, illegal car parks, changes in landscape, etc. The situation can be partly improved thanks to change of drivers' behaviour and building Park and Ride car parks which allow leaving a car on a car park outskirts and continuation of travel by collective transport. To encourage drivers to choose such a way of travelling, one should integrate building and working of car parks with municipal system of collective transport. Identification of travellers' needs can permit better adjustment of infrastructure and organization of collective transport to drivers' expectations and through that to larger popularity of the system as well as improvement of its functioning. The aim of the paper is to present expectations of people travelling by collective transport in context of integration and adjustment of car parks, including Park and Ride car parks, to the system of public communication and travellers' needs. Research methods, which were used, are comparative analysis and questionnaire researches, being realised among drivers, and intending to estimate particular features of car parks. In the article there have been described preferences in domain of collective transport elements, knowledge of which can be used to effective service of Park and Ride car parks' system and collective transport as well as estimation of factors having influence on car parks quality. This information may be used to eliminate quality gap between expectations of travellers using the system and the quality of services supplied.

Keywords: car park, Park and Ride, integration in transportation, drivers' behaviour, travellers' behaviour, collective (public) transport

DOI: $10.7862 / \mathrm{rb} .2016 .284$

Przestano do redakcji: $30.06 .2016 r$.

Przyjęto do druku: 20.12.2016 r. 